\title{
PRESTASI MANAJER JURNALIS PEREMPUAN DI RIAU TELEVISI DALAM PERSEPKTIF KESETARAAN GENDER
}

\author{
Nurhadi \\ Sekolah Tinggi Agama Islam (STAI) Al-Azhar Pekanbaru Riau \\ alhadujurnal@gmail.com \\ Donny Haris \\ Universitas Andalas Padang Sumatera Barat \\ shahzada_dh@yahoo.com
}

\section{ABSTRAK}

Televisi merupakan media massa elektronik yang menjadi salah satu media paling bergengsi bagi para pejuang karir, tanpa terkecuali bagi seorang perempuan. Ada beberapa perempuan yang menempati posisi manajer di Riau Televisi. Penelitian ini bertujuan untuk mengetahui posisi kesetaraan gender jurnalis perempuan di Riau Televisi. Manajemen Riau Televisi memiliki 12 posisi kepemimpinan divisi. Dari beberapa divisi tersebut, hanya empat perempuan yang diposisikan sebagai manejer. Penelitian ini menggunakan metode deskriptif kualitatif dengan data observasi dan wawancara. Data yang terkumpul dikaji dengan teori glass ceiling sebagai alat analisisnya. Hasil penelitian menunjukkan bahwa faktor sosial dan kompetensi sangat menentukan mereka meraih prestasi sebagai manajer jurnalis di Riau Televisi. Dengan demikian prestasi sebagai menejer tak lagi ditentukan oleh jenis kelamin tetapi faktor kecerdasan sosial dan kompetensi lebih menentukan daripada yang lainnya. Penjelasan ini mematahkan anggapan bahwa Riau TV diskriminasi terhadap perempuan dan memperalatnya

Kata Kunci: Prestasi, Manajer Jurnalis Perempuan, Riau Televisi, Kesetaraan Gender, Glass Ceiling. 


\section{ABSTRACT}

Television is an electronic mass media which becomes one of the most prestigious media for career fighters, including those of women. In some television stations, there are women with managerial position. This research aims at identifying the position of women journalists' gender equity in electronic media Riau Television (Riau TV). In terms of management, Riau TV has 12 positions of division leadership, among which only four women are positioned as the managers. This research employed descriptive qualitative method by doing observation and interview as the data. The collected data were examined by glass ceiling theory as the analytical tool. The result of the research showed that social factors and competences had high impact in determining the women's achievement as the journalist managers at Riau TV. Thus, the achievement as the manager was no longer determined by gender. Instead, social intelligence and competence had more influences than any other factors. This explanation broke the assumption that Riau TV discriminated against women and manipulated them.

Keywords: Women Journalist Manager Achievements, Riau TV, Gender Equity, Glass Ceiling.

\section{A. Pendahuluan}

Perempuan dan media adalah salah satu dari 12 isu utama dalam Beijing Platform for Action tahun 1995. Purnamasari (2011) mengungkapkan pembahasan tentang isu keadilan dan kesetaraan gender telah secara intensif dibicarakan sejak tahun 1975 di Konferensi Dunia tentang Perempuan di Mexico, Kopenhagen, Nairobi, sampai Konferensi Beijing pada tahun 1995. Pada tahun 1995, dalam Konferensi Dunia yang keempat tentang Perempuan di Beijing, dihasilkan apa yang dikenal sebagai Beijing Platform for Action yang merupakan landasan aksi baginegara-negara 
di dunia untuk melaksanakan CEDAW (Convention on the Elimination of All Forms of Discrimination Against Women), atau konvensi penghapusan segala bentuk diskriminasi terhadap perempuan. Platform for Action atau Kerangka Aksi ini memberikan fokus kepada Dua belas (12) area kritis yaitu: (1) Perempuan dan Kemiskinan, (2) Perempuan dan Pendidikan, (3) Perempuan dan Kesehatan, (4) Kekerasan terhadap Perempuan, (5) Perempuan dan Konflik Bersenjata, (6) Perempuan dan Ekonomi, (7) Perempuan dalam Kekuasaan dan Pengambilan Keputusan, (8) Mekanisme Kelembagaan untuk Memajukan Perempuan, (9) Hak-Hak Azazi untuk Perempuan, (10) Perempuan dan Media Massa, (11) Perempuan dan Lingkungan Hidup, (12) Anak Perempuan.

Perempuan dalam media selalu menjadi pemanis, pelembut, bahkan perempuan menjadi daya tarik tersendiri mengisi acara-acara atau siaran-siaran di media. Daya tarik yang dimaksud kadang-kadang melecehkan perempuan sendiri karena didalamnya mengambarkan bahwa perempuan adalah makhluk yang lemah yang harus dilindungi, disayangi, kecantikkanya untuk ditonton dan dinikmati oleh semua orang (Nursalim, 2011: 8).

Perempuan dianggap sebagai simbol keindahan sehingga seringkali ditampilkan dalam iklan. Penampilannya pun lekat dengan femininitas serta domestifikasi. Namun seiring munculnya paham feminisme serta gerakan emansipasi perempuan yang membuat pandangan masyarakat bahwa perempuan sebagai "makhluk subordinat" memudar dan kian luntur, kesadaran akan kesetaraan gender juga kerap muncul. Laki-laki pun mulai ditampilkan dan dengan perspektif lain yaitu tidak ditonjolkan sebagai figur yang maskulin dan macho (Kinanti, 2013: 1). 
Keterlibatan perempuan dalam media massa dapat memberikan kontribusi yang sangat besar dalam pemberdayaan dan kemajuan perempuan, tetapi dalam media perempuan dalam posisi marjinal.

Menurut Satriani (2017: xi), bahwa kebijakan untuk perempuan di Harian Amanah disetarakan dengan lakilaki dan perempuan yang mampu mewujudkan mimpimimpi kaum perempuan dan jurnalis perempuan di Harian Amanah ini di haruskan lebih aktif, sesuai dengan profesinya. karena pekerjaan beratpun mereka lakoni sesuai dengan tugas masing-masing.

Akses perempuan rendah terhadap media dan keterlibatan dalam media baik sebagai karyawan maupun sebagai pengambil keputusan dan penggambaran perempuan rendah (Dwi dalam Sastriyani, 2008: 521-522). Masih dalam Beijing Platform for Action, poin kritis lainnya adalah perempuan dalam kekuasaan dan pengambilan keputusan. Bagian ini menginspirasi untuk melihat perempuan sebagai bagian dalam pengelolaan industri media massa.

Perwujudan kesetaraan gender dalam pengelolaan media massa terlihat melalui beberapa aspek. Selain dalam hal jumlah dan kewenangan yang dimiliki antara laki-laki dan perempuan dalam kedudukan yang sama, kesetaraan gender dapat dilihat dari adanya kesadaran dan perlakuan yang sama terhadap laki-laki dan perempuan. Hal ini dapat dilihat pada aspek promosi jabatan dalam industri media. Promosi jabatan menggambarkan promosi karir dalam organisasi birokratis.

Artikel ini ingin menunjukkan bahwa wujud kesetaraan gender tidak semata-mata terlihat dari aspek jumlah yang sama antara laki-laki dan perempuan di suatu posisi yang setara, melainkan perlu dilihat dari aspek 
kesamaan perlakuan, hak dan kewajiban laki-laki dan perempuan. Dari 12 divisi di Riau Televisi, hanya terdapat empat divisi yang dipimpin perempuan dari total 32 perempuan yang menjadi karyawan Riau Televisi.

\section{Tabel I}

Karyawan Riau Televisi Berdasarkan Jenis Kelamin dan Divisi Tahun 2017

\begin{tabular}{|c|c|c|c|}
\hline \multirow{2}{*}{ Divisi } & \multicolumn{2}{|c|}{ Jenis Kelamin } & \multirow{2}{*}{ Jumlah } \\
\hline & Laki-laki & Perempuan & \\
\hline $\begin{array}{l}\text { 1. Redaksi } \\
\text { 2. Umum \& SDM } \\
\text { 3. Marketing } \\
\text { 4. Keuangan \& Fiskal } \\
\text { 5. Program \& Studio } \\
\text { 6. Produksi } \\
\text { 7. Event Organizer } \\
\text { 8. Tv Jaringan } \\
\text { 9. Kreatif \& PH } \\
\text { 10. Teknik \& } \\
\text { Pemeliharaan } \\
\text { 11. Bisnis Kreatif } \\
\text { 12. Website \& Streaming }\end{array}$ & $\begin{array}{r}32 \\
8 \\
4 \\
2 \\
21 \\
18 \\
4 \\
9 \\
6 \\
10 \\
15 \\
6\end{array}$ & $\begin{array}{l}8 \\
2^{*} \\
5^{*} \\
2 \\
3 \\
2 \\
1 \\
- \\
2 \\
2 \\
1^{*} \\
4^{*}\end{array}$ & $\begin{array}{r}40 \\
10 \\
9 \\
4 \\
24 \\
20 \\
5 \\
9 \\
8 \\
12 \\
16 \\
10\end{array}$ \\
\hline Jumlah & 135 & 32 & 167 \\
\hline
\end{tabular}

Sumber: diolah dari data divisi umum dan sdm * divisi yang dipimpin perempuan.

Berikut ini disajikan data perempuan-perempuan yang menempati posisi manajer di Riau Televisi sejak didirikan hingga tahun 2017. 


\section{Tabel II}

Manajer Perempuan di Riau Televisi Tahun 2001-2017

\begin{tabular}{llc}
\hline \multicolumn{1}{c}{ Nama } & \multicolumn{1}{c}{ Jabatan } & Tahun \\
\hline Sulastri & Manajer Umum \& SDM & $2001-2017$ \\
\hline Susi Dewi & Manajer Marketing & $2001-2008$ \\
& Asisten GM/ PO RTV Rengat & $2009-2010$ \\
\hline & Manajer Pemberitaan/ Pemimpin & \\
& Redaksi & \\
& Asisten GM/ PO RTV Siak \& RTV & $2005-2009$ \\
& Kuansing & $2009-2010$ \\
Laras Hati & Wakil GM Bidang Pengembangan & $2010-2013$ \\
& Usaha \& Redaksi & $2013-2016$ \\
& Wakil GM Bidang Pengembangan & $2016-2017$ \\
& Usaha \& Program & \\
& Manajer Bisnis Kreatif & $2010-2011$ \\
& Manajer Pemberitaan/ Pemimpin & $2012-2014$ \\
& Redaksi & $2015-2016$ \\
Luna Agustin & Manajer Program \& Studio & $2016-2017$ \\
& Manajer Produksi & $2011-2015$ \\
\hline Murparsaulian & Manajer Website \& Streaming & $2011-2017$ \\
\hline Tri Hirda Putri & Manajer Produksi & \\
\hline
\end{tabular}

Sumber: diolah dari data Divisi Umum \& SDM

Didukung minat terhadap kajian gender dan media massa, artikel ini menyajikan hasil penelitian tentang perempuan yang menduduki posisi manajer di Riau Televisi. Walau kajian tentang perempuan dan media massa cukup banyak dilakukan, penelitian mengenai perempuan yang menduduki posisi manajer dan kaitannya dengan kesetaraan dan keterlibatan perempuan pada posisiposisi penting pengelolaan media massa masih sedikit. Pertanyaan yang akan dijawab adalah bagaimanakah situasi dan kondisi manajer perempuan di Riau Televisi? Bagaimanakah promosi jabatan yang tidak diskriminatif 
gender di Riau TV? dan bagaimanakah penempatan karir bagi manajer perempuan: kesetaraan gender atau diperalat?

Oakley mengartikan gender sebagai konstruksi sosial atau atribut yang dikenakan pada manusia yang dibangun oleh kebudayaan manusia (Nugroho, 2014: 2-3). Perempuan secara badaniah, wanita berbeda dengan lakilaki. Alat kelamin wanita berbeda dengan laki-laki. Wanita punya buah dada yang lebih besar. Suara wanita lebih halus. Wanita melahirkan anak. Dan sebagainya (Budiman, 2015: 1). Kata gender dalam khasanah ilmu-ilmu sosial, memunculkan istilah seks secara sederhana, misalnya dapat diartikan sebagai pembagian jenis kelamin yang ditentukan secara biologis yang melekat pada jenis kelamin tertentu (Agustino dalam Sastriyani, 2013: 506). Gender mengacu kepada peran atau sifat-sifat yang diberikan masyarakat terhadap orang, seperti siapa yang mencuci pakaian dan siapa yang mengemudi mobil di dalam keluarga, atau siapa yang harus lemah dan siapa yang harus kuat (Stewart, 2012: 187).

Gender adalah konsep hubungan sosial. Pembedaan fungsi dan peran antara laki-laki dan perempuan itu tidak ditentukan karena keduanya terdapat perbedaan biologis atau kodrat, melainkan dibedakan menurut kedudukan, fungsi dan peranan masing-masing dalam berbagai bidang kehidupan dan pembangunan (Narwoko \& Suyanto, 2013: 334-335). Secara umum, imajinasi tentang kepemimpinan ideal seringkali merupakan bentukan struktural dan kultural (Aripurnami, 2013: 63). Bila ada perempuan yang inginmemasuki wilayah ini, maka ia harus orang yang hebat, istimewa, dan mampu bersaing dengan laki-laki. Sampai saat ini pandangan tersebut masih dianut masyarakat umumnya, baik di Indonesia, maupun di Amerika dan Eropa (Lidyah, 2017: 2). Teori Giddens ini merujuk kepada 
"dualitas struktur." Tidak hanya struktur itu menghambat dan menentukan bentuk-bentuk tertentu perilaku, tetapi juga memberikan kemampuan bagi perilaku; struktur memberikan kesempatan dan pembatasan sekaligus (Giddens, 2010: 240).

Teori strukturasi merujuk kepada "dualitas struktur". Tidak hanya struktur itu menghambat dan menentukan bentuk-bentuk tertentu perilaku, tetapi juga memberikan kemampuan bagi perilaku; struktur memberikan kesempatan dan pembatasan sekaligus (Jones, 2010: 240). Menurut Giddens penting dicatat bahwa struktur tidak hanya menimbulkan kendala (constraint) bagi tindakan manusia, tetapi juga menimbulkan peluang bagi manusia untuk bertindak atas kehendak sendiri (Wirawan, 2015: 296).

Seperti yang dijelaskan Kusno, terdapat rintangan bagi perempuan untuk naik ke tingkat atau posisi yang lebih tinggi dalam suatu manajemen perusahaan. Rintangan itu dikenal dengan konsep langit-langit kaca atau kubah kaca atau Glass Ceiling (Kusno, 2015). Untuk pemahaman lebih baik tentang pengertian langit-langit kaca dalam kaitan menghambat dan merintangi perempuan, digambarkan Henslin melalui sebuah pertanyaan, apa yang menghalangi perempuan untuk menembus langit-langit kaca (glass ceiling), hambatan yang umumnya tak tampak, yang menghalangi perempuan menjadi eksekutif? Dalam penjelasannya lebih lanjut, Henslin juga mengurai konsep ini dengan mengutip dua sumber berbeda, yaitu tentang para peneliti yang mengidentifikasi suatu "jalur" yang menuju ke posisi puncak - posisi pemasaran, penjualan dan produksi yang secara langsung berpengaruh kepada pendapatan yang dihasilkan perusahaan (Reich, 1995; Clarke, 2000 dalam Henslin, 2007). 
Di Indonesia, langit-langit kaca tersebut didasari oleh kultur masyarakat patriarkis yang menilai laki-laki lebih penting daripada perempuan (Sarwono, 2013: 2). Sebagai akibatnya, perempuan yang menjadi bagian dan bekerja di media massa, terpaksa berhadapan dengan kesulitan menembus langit-langit kaca untuk mencapai posisiposisi penting dan strategis. Perempuan juga menjadi obyek dari patriarki yang telah menciptakan tindakan yang membedakan, menghasilkan lapisan-lapisan dalam interaksi antara laki-laki dan perempuan, dan berujung pada ketidaksetaraan dan ketidakadilan (Wijayanti, 2009).

Wanita dalam manajemen menjadi topik penting (Wentling, 2003). Hal itu terkait dengan adanya peningkatan pekerja wanita tetapi hanya sedikit yang menduduki posisi senior level management. Wanita hanya mampu mencapai posisi middle level management yaitu seseorang yang menjalankan strategi atau kebijakan dari senior level management (Wentling, 2003).

Fenomena itu dikenal sebagai glass ceiling dan terkenal mulai tahun 1980-an (Burke, 2006). Gless ceiling merupakan pandangan bahwa, wanita dapat diterima sebagai karyawan perusahaan, tetapi mempunyai kesulitan untuk dipromosikan, terutama pada posisi senior level management (Stoner et. al., 1996). Wanita dapat melihat peluang di atas tetapi tidak dapat mencapainya. Menurut Burke (2006), glass ceiling merupakan hambatan yang membatasi kelanjutan karir wanita mencapai posisi yang lebih tinggi. Dalam mencapai posisi tersebut seolah-olah ada hambatan yang tidak nampak (Stoner et. al., 1996).

Ada tiga hambatan menurut Federal Glass Ceiling Commision dalam Wentling (2003). Pertama, hambatan organisasional yang meliputi kegagalan dalam rekrutmen, pengembangan, dan dukungan terhadap wanita untuk 
mencapai posisi senior level management. Kedua, hambatan societal yang bersumber dari hambatan organisasional. Hambatan ini menganggap wanita kurang mempunyai komitmen terhadap karir. Ketiga, hambatan govermental, disebutkan bahwa pemerintah kurang terlibat dalam fenomena glass ceiling (Muslim dan Perdhana, 2017).

Menurut Weyer (2007), tiga kategori yang merupakan hambatan dalam fenomena glass ceiling adalah (Wijayanti, 2009): 1) praktek-praktek seperti rekrutmen, retensi, dan promosi. Perusahaan cenderung memilih karyawan lakilaki karena dianggap mempunyai kemampuan yang lebih dari pada wanita. Wanita sudah tidak diberi kesempatan untuk membuktikan dirinya, bahwa mempunyai kemampuan yang sama dengan laki-laki. 2). Perilaku dan budaya misalnya stereotype dan gaya kepemimpinan. Manajer wanita banyak digambarkan kurang mempunyai karakteristik untuk menjadi manajer yang sukses (Cai and Clainer, 1999). 3). Struktur dan budaya yang dijelaskan secara mendalam dalam feminist theory (Muslim dan Perdhana, 2017).

Penelitian ini dilaksanakan selama enam bulan mulai Mei sampai dengan November 2018 di Riau Televisi, Kota Pekanbaru, Provinsi Riau sebagai lokasi penelitian (Bogdan dan Taylor (1993: 63). Metode penelitian kualitatif digunakan dalam penelitian ini, dengan mengobservasi subjek penelitian yaitu informan (Horton, 1999: 5-7). Metode penelitian kualitatif merupakan metode yang diterapkan dalam banyak kasus penelitian (Bungin, 2012: 93). Ada empat kasus perempuan yang berhasil menempati posisi manejer di Riau TV yang telah dipelajari dengan menggunakan teknik wawancara mendalam (Sugiyono, 2012: 24-25). Selain itu, penelitian ini juga merupakan 
penelitian feminis yaitu menemukan realitas dari sudut perempuan dengan perempuan dijadikan informan utama (Afrizal, 2014; Moleong, 2011: 90). Peneliti memilih istilah "penelitian berorientasi gender" (gender oriented research) untuk semua penelitian yang sadar gender dan penelitian berfokus gender (Holzner dalam Saptari \& Holner, 1997: 449).

\section{B. Pembahasan}

\section{Manajer Perempuan di Riau Televisi}

Realitas perempuan yang menduduki posisi manajer di Riau Televisi bukan potret sekedar berbagi kesempatan dengan memberikan afirmasi kepada perempuan untuk ikut serta dalam pengelolaan media massa, melainkan pengakuan dari manajemen bahwa perempuan pantas menduduki posisi tersebut. Dua perempuan telah menjadi bagian dari jajaran pimpinan perusahaan dengan menduduki posisi manajer marketing dan manajer umum dan sdm di awal Riau Televisi didirikan dan mulai beroperasi. Selain di kedua posisi tersebut, keberadaan perempuan juga terdapat di sejumlah divisi di Riau Televisi. Di dalam penelitian ini terdapat empat perempuan yang menduduki posisi manajer dan merupakan informan utama penelitian.

Hingga akhirnya menduduki posisi manajer umum dan sdm Riau Televisi, bagi Sulastri tidak terjadi begitu saja. Sebelum menduduki posisi tersebut, ia telah memiliki pengalaman kerja selama 10 tahun di Harian Riau Pos di berbagai posisi dan bidang kerja. Kondisi relatif sama dari aspek pengalaman kerja di media massa sebelum menjadi karyawan Riau Televisi, juga dimiliki Laras Hati dan Luna Agustin. Keduanya berlatar belakang pengalaman di bidang jurnalistik. Sebelum memutuskan bergabung ke 
Riau Televisi atas tawaran pimpinan perusahaan di awal Riau Televisi didirikan, kedua perempuan ini memiliki sejumlah pengalaman yang diandalkan perusahaan di bidang jurnalistik. Baik Laras Hati maupun Luna Agustin, keduanya juga pernah menduduki sejumlah posisi di dalam struktur keredaksian Harian Riau Pos. Di saat penelitian dilaksanakan, Laras Hati menduduki posisi manajer bisnis kreatif dan Luna Agustin di posisi manajer web dan streaming Riau Televisi. Terakhir, Tri Hirda Putri, manajer pemasaran. Ia memiliki latar belakang pendidikan yang sesuai dengan bidang yang menjadi tanggung jawabnya sebagai seorang manajer pemasaran. Tri Hirda Putri menjalani karirnya selama sembilan tahun hingga akhirnya menduduki posisi manajer, setelah sebelumnya dipromosi mulai dari staf hingga asisten manajer.

Perempuan sebagai bagian pengelolaan media massa, mesti dilihat secara menyeluruh. Kenyataan di Riau Televisi menunjukkan, terdapat perempuan yang menduduki posisi manajer di sejumlah divisi di dalam struktur organisasi media massa tersebut. Adanya perempuan yang menduduki posisi manajer di Riau Televisi telah berlangsung seiring media massa elektronik bidang penyiaran ini didirikan. Di masa awal Riau Televisi yang melakukan siaran perdananya secara resmi pada 20 Mei 2001, media massa yang tergabung di dalam Riau Pos Media Grup ini telah memiliki manajer-manajer perempuan.

Sejak Riau Televisi didirikan, media massa ini tidak hanya memiliki empat manajer perempuan yang menjadi fokus penelitian ini. Sejak mulai beroperasi di tahun 2001, terdapat enam perempuan yang menempati posisi manajer. Sulastri merupakan perempuan yang ditunjuk Direktur Utama PT Riau Media Televisi untuk menduduki posisi manajer umum dan sdm sejak awal ia bekerja di 
perusahaan ini. Namun penunjukan tersebut bukan tanpa sebab, melainkan dilatarbelakangi rekam jejak pengalaman, kemampuan dan karirnya sejak ia mulai menjadi karyawan di Harian Riau Pos dan berlanjut hingga Riau Televisi didirikan. Sebelum menduduki posisi Manajer Umum dan SDM di Riau Televisi, Sulastri memulai karirnya sebagai Sekretaris Redaksi Harian Riau Pos, Kepala Bagian Umum Divisi Umum, dan Kepala Bagian Piutang Divisi Iklan Riau Pos. Semua posisi tersebut dijalaninya selama enam tahun mulai tahun 1991 hingga 1997. Di tahun 1997 hingga 2001, Sulastri dipromosikan menduduki posisi Manajer Keuangan Patria Tour dan Meganet, yang merupakan anak perusahaan Riau Pos.

Kebijakan yang sama juga dilakukan oleh manajemen terhadap Susi Dewi Yanti yang menempati posisi Manajer Marketing Riau Televisi. Ia menempati posisi ini mulai tahun 2001 hingga 2008. Sebelum bekerja di lingkungan perusahaan dan media massa grup Riau Pos, Susi Dewi Yanti telah bekerja di Koran Watan. Di lingkungan media Riau Pos Grup, Susi Dewi Yanti pernah menduduki posisi manajer iklan di Patria Tour dan Meganet, salah satu anak perusahaan Riau Pos sebelum berkarir di Riau Televisi. Karir Susi Dewi Yanti selanjutnya, ia dipromosikan menduduki posisi manajer marketing di Riau Televisi. Ia juga dipromosikan menjadi wakil general manager dengan tugas mengelola televisi lokal hasil kerjasama Riau Televisi dengan Pemerintah Kabupaten Indragiri Hulu. Karirnya berakhir seiring mengundurkan diri di tahun 2010.

Manajer perempuan berikutnya yaitu Laras Hati. Ia memulai karirnya di Riau Televisi sejak tahun 2001 dengan posisi sebagai penanggung jawab khusus di Divisi Redaksi. Berselang empat tahun kemudian, yaitu di tahun 2005 ia menempati posisi sebagai pemimpin redaksi. Posisi sebagai pemimpin redaksi atau manajer pemberitaan 
dijalaninya hingga tahun 2009. Masih di tahun 2009, sejalan pengembangan usaha Riau Televisi yang menjalin kerjasama dengan tiga pemerintah kabupaten di Provinsi Riau, yaitu Pemerintah Kabupaten Siak, Pemerintah Kabupaten Kuantansingingi dan Pemerintah Kabupaten Indragiri Hulu berupa pendirian televisi lokal di daerah, Laras Hati ditunjuk menduduki posisi Asisten General Manager/ Penanggungjawab Operasional RTV Siak dan RTV Kuansing. Sepanjang tahun 2010 hingga 2016, Laras Hati menduduki posisi Wakil General Manager Bidang Pengembangan Usaha dan Redaksi, dan Wakil General Manager Bidang Pengembangan Usaha dan Program.

Luna Agustin memulai karirnya sebagai reporter redaksi Riau Televisi di tahun 2001. Sebelumnya, Luna Agustin adalah wartawati Harian Riau Pos yang pernah menduduki sejumlah posisi di struktur keredaksian harian tersebut. Posisi manajer di Riau Televisi didudukinya kali pertama di tahun 2010. Di tahun-tahun berikutnya, ia menempati posisi Manajer Program \& Studio, Manajer Produksi dan terakhir Manajer Website \& Streaming yang menaungi detakriaunews.com.

Manajer perempuan berikutnya yaitu Muparsaulian. Seperti Luna Agustin yang memulai karirnya di Riau Televisi sebagai reporter redaksi, Murparsaulian menduduki posisi manajer produksi di tahun 2010 hingga tahun 2015. Sebelumnya, ia merupakan reporter di divisi redaksi. Posisi yang pernah didudukinya sebelum menjabat sebagai manajer produksi yaitu asisten manajer produksi. Di tahun 2016, Murparsaulian mengundurkan diri. Terakhir, Tri Hirda Putri yang menduduki posisi manajer marketing dan mulai tahun 2011 hingga 2017. Berbeda dengan manajer-manajer perempuan lainnya, Tri Hirda Putri tidak memiliki pengalaman kerja sebelum memulai karirnya sebagai karyawan Riau Televisi. Staf administrasi 
adalah posisi yang didudukinya saat kali pertama ia diterima bekerja sebagai karyawan di Riau Televisi.

Posisi pimpinan divisi yang diduduki keenam manajer perempuan ini memiliki andil dan pengaruh signifikan di dalam operasional perusahaan. Hal ini dibuktikan melalui posisi yang diduduki para manajer perempuan ini, bahwa enam divisi yang mereka pimpin merupakan divisi yang diperhitungkan, seperti divisi pemasaran, produksi serta divisi umum dan sdm. Penggambaran ini sejalan seperti yang diungkapkan Henslin (2007: 59-60), yaitu bahwa posisi pemasaran, penjualan dan produksi yang secara langsung berpengaruh kepada pendapatan yang dihasilkan perusahaan.

\section{Promosi Jabatan yang tidak Diskriminatif Gender}

Dari penggambaran perempuan yang menduduki posisi manajer di Riau Televisi, bagaimana penjelasan tentang kesetaraan gender antara laki-laki dan perempuan di Riau Televisi? Apabila asumsinya bahwa pengalaman, kemampuan, prestasi, masa kerja, latar belakang pendidikan dan kontribusi seperti memberikan omzet ke Riau Televisi sebagai syarat promosi untuk posisi manajer, apakah ini berlaku sama terhadap karyawan laki-laki dan perempuan?

Organisasi media televisi adalah organisasi bisnis. Hal sama juga terdapat pada Riau Televisi sebagai stasiun televisi lokal. Perekrutan tenaga kerja sebagai sumber daya yang dibutuhkan untuk menjalankan operasional di Riau Televisi tidak diskriminatif gender atau bersifat membedakan dan menghalangi perekrutan karyawan hanya pada jenis kelamin tertentu. Selain itu, Riau Televisi juga bukan media massa yang khusus mempekerjakan laki-laki. Dengan demikian, baik laki-laki dan perempuan yang dinilai memenuhi kriteria dan syarat dalam proses 
perekrutan memiliki peluang yang sama untuk diterima menjadi karyawan dan menempati posisi-posisi yang tersedia sesuai kebutuhan perusahaan dan penilaian manajemen. Direktur Utama PT Riau Media Televisi, Makmur Kasim, menegaskan bahwa perusahaan ini tidak membedakan jenis kelamin dalam penerimaan karyawan. Apabila persyaratan yang diluncurkan manajemen ketika melakukan perekrutan dapat dipenuhi pelamar atau calon karyawan laki-laki maupun perempuan tidak ada alasan pihaknya melakukan penolakan. Ketentuan dan keputusan manajemen tentang perekrutan, proses hingga hasil berupa penerimaan karyawan merupakan hak penuh direktur utama. Hal sama juga berlaku bagi peningkatan karir seseorang melalui promosi jabatan ke jenjang yang lebih tinggi.

Terkait adanya empat perempuan yang menduduki posisi manajer, Makmur Kasim juga mengungkapkan kriteria yang dijadikan untuk menunjuk dan mengangkat perempuan menduduki posisi tersebut yaitu soal kemampuan. Dengan adanya kemampuan yang dimiliki maka perempuan dapat melaksanakan tugasnya sesuai job desk masing-masing. Kemampuan itu didukung ilmu, keterampilan dan pengalaman yang cukup. Menyangkut latar belakang pendidikan dan keilmuan, yang diperlukan tentu saja disiplin ilmu yang berhubungan dengan tugas mereka, walaupun bukan persyaratan mutlak. Di Riau Televisi, sangat mungkin ketika seorang karyawan yang berlatar belakang pendidikan tamat sma sekalipun menduduki posisi manajer. Hal tersebut bukan sesuatu di luar kelaziman, sejauh yang bersangkutan memiliki kemampuan. Ia mencontohkan, karyawan yang memiliki penguasaan bidang keredaksian dan bekal ilmu jurnalistik memadai, memiliki prioritas untuk ditempatkan di bagian ini ataupun menjadi pimpinannya. Kemudian di divisi 
marketing tentu saja berkaitan dengan ilmu marketing. Demikian juga di divisi umum dan sdm, karyawan dengan pengalaman dan penguasaan ilmu yang menyangkut personalia atau manajemen sumber daya manusia jelas dibutuhkan.

Dari penjelasan tentang bagaimana seorang karyawan dinilai hingga diputuskan untuk dipromosi ke posisi lebih tinggi, menunjukkan adanya penilaian yang tidak diskriminatif gender. Adapun penilaian yang tidak diskriminatif gender tersebut artinya mengarah kepada adanya kesetaraan gender, yaitu terdapat keadilan bagi laki-laki dan perempuan dalam kesempatan dan penilaian dalam peluang menduduki suatu posisi di dalam struktur Riau Televisi. Pandangan yang tidak diskriminatif gender berarti pandangan yang tidak membedakan, atau memandang adanya keadilan atau kesetaraan antar kedua jenis kelamin laki-laki dan perempuan dalam menempati posisi di dalam perusahaan. Tidak hanya pada posisi jajaran pimpinan perusahaan, namun juga di berbagai divisi yang ada di Riau Televisi.

Pandangan yang tidak diskriminatif gender juga yang telah membuka pintu bagi perempuan menduduki posisi manajer di Riau Televisi. Dari hasil pengamatan dan analisis peneliti, kesetaraan gender di Riau Televisi secara khusus terhadap isu di dalam penelitian ini yaitu keberadaan perempuan di posisi manajer sebagai bentuk kesetaraan gender, memang belum mencapai tingkat ideal jika dikaitkan dengan asumsi bahwa kesetaraan dimaksud adalah kesamaan jumlah. Isu kesetaraan dalam penelitian ini adalah tentang kebijakan dan aturan perusahaan serta perlakuan yang berlaku sama terhadap laki-laki dan perempuan dalam kesempatan atau peluang promosi jabatan yang ada, tidak mengandung unsur dan perlakuan yang membedakan karena perbedaan identitas gender. 
Membahas kesetaraan berarti membahas keadilan. Kesetaraan gender adalah kesetaraan seperti posisi dan peran, sehingga dalam setiap aktifitas dan tanggung jawab laki-laki dan perempuan berada dalam tingkat dan porsi yang sama. Kesetaraan gender juga tidak luput dari tentang bagaimana mengungkap persoalan peluang terbuka dan perlakuan sama yang bersifat timbal balik antar kedua jenis kelamin. Di dalam penelitian ini, untuk menjelaskan kesetaraan gender menggunakan parameter dengan tujuan menegaskan bahwa konsep kesetaraan dimaksud tidak mengambang, sehingga bersifat teruji dan terukur. Selain itu juga berfungsi sebagai alat ukur untuk menjelaskan konsep kesetaraan gender tersebut. Untuk mengetahui sistem yang digunakan dalam promosi jabatan sebagai suatu keputusan yang menggunakan kesetaraan, diketahui dari parameter yang digunakan.

Parameter pertama yang digunakan untuk menganalisis kesetaraan gender di dalam penelitian ini, yaitu penilaian atau nilai yang dicapai laki-laki dan perempuan berada di standar atau ukuran yang sama. Promosi jabatan berupa peningkatan karir dari suatu posisi ke jenjang atau tingkat yang lebih tinggi diberlakukan atas pencapaian nilai tertentu. Di Riau Televisi, standar nilai promosi jabatan dilakukan jika seorang karyawan berhasil mencapai nilai $\mathrm{A}$ atau dengan angka minimal 85. Dengan demikian, apabila seorang karyawan laki-laki dipromosikan ke suatu posisi tertentu karena mencapai nilai A, maka hal sama juga berlaku bagi karyawan perempuan, ataupun berlaku sebaliknya. Kesetaraan dalam penilaian ini tidak disebut sebagai kesetaraan apabila salah satu baik laki-laki atau perempuan ditoleransi dan mendapat perlakuan berbeda atau keputusan yang bersifat permisif hanya karena identitas gendernya. Sebagai contoh, hanya karena identitas gendernya sebagai laki-laki dengan masa 
kerja yang lebih lama namun hanya mencapai nilai $\mathrm{B}$, dan dipromosikan ke jenjang yang sama dengan perempuan yang memiliki masa kerja yang sama namun pencapaian nilai lebihh tinggi, kondisi ini tidak disebut sebagai kesetaraan gender dalam penilaian dan promosi jabatan. Hal ini karena terdapatnya pembedaan dan ketidakadilan yang disebabkan pandangan berbeda dan pembedaan terhadap identitas gender tertentu. Di dalam penelitian ini, seluruh karyawan yang menduduki posisi manajer, baik laki-laki maupun perempuan merupakan karyawan yang dinilai mampu dan berhasil memenuhi kriteria penilaian dengan nilai A.

Parameter kedua yaitu pengalaman dan masa kerja. Mencuatnya empat perempuan yang menduduki posisi manajer di Riau Televisi, juga berkaitan dengan masa kerja yang panjang. Keempat manajer perempuan di dalam penelitian ini telah menjalani masa kerja lebih dari 15 tahun. Masa kerja ini dihitung ketika mereka mulai bekerja di Riau Televisi. Senioritas semata ternyata juga tidak menjadi jaminan dan penjelasan terhadap pertanyaan, mengapa dan bagaimana empat karyawan perempuan senior ini menduduki posisi manajer. Bagian ini mengacu kepada pengalaman dan masa kerja yang dimiliki karyawan laki-laki dan perempuan. Dari 12 posisi manajer di Riau Televisi, terkait posisi yang diduduki saat penelitian ini dilaksanakan, seluruhnya diukur dari pengalaman dan masa kerja mereka di Riau Televisi. Temuan khusus terjadi pada informan Sulastri yang ditunjuk langsung menduduki posisi manajer umum dan sdm. Akan tetapi, dibalik itu Sulastri memiliki pengalaman dan masa kerja yang relatif lama di perusahaan di lingkungan Riau Pos Grup. Selebihnya, baik manajer laki-laki maupun perempuan yang menduduki posisi manajer, memulai karir mereka dari bawah ketika menjadi karyawan Riau Televisi. 
Parameter ketiga adalah latar belakang dan tingkat pendidikan. Latar belakang dan tingkat pendidikan seorang karyawan tidak merupakan syarat mutlak atau bersifat menghalangi yang bersangkutan untuk menduduki posisi manajer apabila tidak terpenuhi. Dari pengumpulan dokumen selama penelitian berlangsung, data yang diperoleh menunjukkan bahwa terdapat lakilaki dengan jenjang pendidikan sekolah menengah atas atau sederajat seperti smk atau stm yang menduduki posisi manajer. Kondisi yang sama juga ditemukan pada karyawan perempuan berlatar pendidikan yang sama. Empat perempuan yang menjadi informan penelitian ini, dua diantaranya adalah tamat sma. Sementara dari tujuh manajer laki-laki, juga terdapat manajer dengan latar belakang atau tingkat pendidikan sma atau sederajat. Hal serupa juga dapat dilihat dari para manajer yang memiliki tingkat pendidikan strata satu baik laki-laki maupun perempuan.

\section{Manajer Perempuan: Kesetaraan Gender atau Diperalat?}

Posisi manajer di Riau Televisi yang ditempati lakilaki dan perempuan, tidak serta merta menjelaskan realitas tersebut sebagai bentuk kesetaraan gender. Mengacu kepada definisi kesetaraan gender adalah keadilan gender, dan keadilan tersebut ditunjukkan dengan tidak membedakan perlakuan antar kedua jenis kelamin, maka pokok persoalannya bukan pada kesamaan atau keseimbangan pada jumlah posisi yang ditempati laki-laki ataupun perempuan. Pemikiran mendasar dalam persoalan ini adalah adanya kesamaan dalam perlakuan, kesempatan dan sistem yang diberlakukan dalam promosi jabatan, hingga kebijakan yang diterapkan kepada karyawan laki-laki dan perempuan. Pada bagian ini termasuk hak, 
kewajiban dan tanggung jawab, baik karyawan laki-laki maupun perempuan. Memperlakukan sama dan tidak membedakan karena identitas gender sebagai bukti kesetaraan ditemukan seperti pada penilaian dan promosi jabatan, ataupun kesempatan yang sama saat berpendapat dalam rapat-rapat yang digelar dengan melibatkan manajer laki-laki dan perempuan.

Memanfaatkan atau bahkan memperalat perempuan dengan menempatkan mereka di posisi manajer, karena alasan kasihan atau hanya sebagai sekadar berbagi posisi dan kesempatan dalam konteks tersebut merupakan strategi perusahaan untuk memperoleh pendapatan sebesar-besarnya, perlu dikaitkan dengan penjelasan lain dalam temuan hasil wawancara dan pengamatan di dalam penelitian ini. Bagian dimaksud yaitu apabila asumsi bahwa perempuan memiliki kemampuan dan kelebihan dalam pengelolaan keuangan, tentu saja tidak tepat atau menjadi keputusan yang keliru menempatkan laki-laki di posisi manajer keuangan seperti yang terdapat di Riau Televisi. Penjelasan ini dihubungkan dengan pandangan bahwa keterlibatan perempuan di sektor publik sesungguhnya bentuk keterwakilan perempuan di ranah domestik yang dipindahletakkan ke sektor publik. Artinya, pekerjaan-pekerjaan yang dilabel membutuhkan sifat-sifat yang dikenakan sebagai milik perempuan, tidak semestinya dilakoni laki-laki. Kenyataan di Riau Televisi menunjukkan, posisi manajer keuangan justru ditempati laki-laki dengan latar belakang pendidikan diploma tiga akuntansi. Dari penelusuran data tentang latar belakang karyawan Riau Televisi, ternyata tidak terdapat karyawan berlatar belakang keilmuan akuntansi dengan jenjang strata satu apabila kriteria tersebut merupakan syarat menduduki posisi manajer keuangan. 
Sebaliknya, posisi manajer teknik, studio dan pemeliharaan di Riau Televisi hingga kini tidak pernah diduduki perempuan. Menurut General Manajer Riau Televisi Sumedi Susanto, sejak awal didirikan tidak terdapat perempuan yang memiliki kemampuan di bidang ini. Selain itu, dalam proses perekrutan karyawan yang memiliki pengalaman dan kemampuan di bidang teknik, ditemukan bahwa bidang ini lebih diminati dan didominasi laki-laki bahkan saat dilakukan perekrutan tenaga kerja. Kenyatan ini akhirnya memberikan suatu pandangan bahwa menempatkan seseorang di posisi manajer di Riau Televisi, berhubungan dengan dimilikinya pengalaman, kemampuan dan prestasi sebagai syarat dan kriteria yang dibutuhkan untuk menduduki posisi tersebut. Selain itu, sistem penilaian yang sama terhadap laki-laki maupun perempuan serta pimpinan perusahaan yang tidak berpandangan diskriminatif gender terhadap perempuan, merupakan penyebab perempuan menduduki posisi manajer.

Jika dinyatakan adalah keputusan yang tepat untuk menempatkan keempat perempuan ini diposisi yang kini mereka duduki, justru sebaliknya. Pertama, latar belakang pendidikan tiga dari empat manajer ini tidak mendukung dan memiliki kaitan langsung atau memiliki relevansi dengan bidang kerja atau divisi yang mereka pimpin. Hanya Tri Hirda Putri yang memiliki kesesuaian karena ia lulusan ilmu ekonomi dan menempati posisi manajer marketing. Kedua, tingkat pendidikan dua dari empat manajer ini adalah lulusan sma. Latar belakang dan tingkat pendidikan, misalnya strata satu tidak menjadi syarat utama yang mesti dipenuhi seseorang untuk menempati atau dipromosi menjadi manajer di Riau Televisi. Terbukti dua dari empat manajer perempuan di Riau Televisi hanya lulus sma. Di kalangan manajer laki-laki, dari delapan manajer yang ada, 
tiga diantaranya tidak memiliki pendidikan strata satu, masing-masing dua lulusan sma dan satu lainnya diploma tiga.

Realitas yang dapat diamati dan terdapat di masyarakat, banyaknya perempuan yang bekerja bersama laki-laki bukan menjelaskan kesetaraan gender, melainkan sebagai pandangan bahwa perempuan tepat di posisi tertentu, misalnya sales promotion girls karena perempuan dipandang lebih persuasif di posisi itu. Menempatkan perempuan di situ bukan sebuah keseteraan melainkan memperalat.

Melalui penelitian yang berlangsung selama enam bulan ini, ditemukan hasil, yaitu realitas perempuan yang menduduki atau menempati posisi manajer di Riau Televisi, bukan potret yang menggambarkan suatu bentuk berbagi posisi karena rasa kasihan. Dimilikinya pengalaman, kemampuan, masa kerja dan prestasi oleh empat perempuan ini, merupakan sejumlah persyaratan yang menjadi pertimbangan direktur utama dalam memutuskan untuk menempatkan perempuan di posisi manajer. Posisi direktur utama memiliki kewenangan penuh dalam keputusan promosi seorang karyawan. Penilaian terhadap kinerja yang mencakup kriteria tertentu, diberlakukan sama tanpa membedakan karyawan laki-laki dan perempuan. Pada dasarnya terdapat perlakuan sama dalam mempromosikan baik laki-laki maupun perempuan untuk menempati suatu posisi, dalam konteks penelitian ini dengan focus posisi manajer. Adanya perlakuan sama itu pula sebagai substansi kajian gender yang bermula dari ketidakadilan menuju kesetaraan. Bagian mendasar adalah bahwa pandangan direktur utama sebagai pihak yang memiliki kewenangan penuh, ternyata tidak diskriminatif gender. Artinya, direktur utama tidak memiliki persepsi dan asumsi negatif terhadap perempuan. Tidak ada norma 
atau aturan yang menghalangi perempuan ditempatkan di posisi manajer. Dengan demikian, posisi manajer di Riau Teevisi terbuka bagi laki-laki dan perempuan sejauh bahwa kedua jenis kelamin dinilai memenuhi persyaratan untuk posisi tersebut.

Menempatkan perempuan di posisi manajer dilaksanakan melalui sejumlah tahapan sesuai aturan yang ditetapkan pimpinan Riau Televisi. Penilaian yang meliputi kinerja, sikap, kemampuan, keterampilan dan loyalitas merupakan bagian mendasar yang diperlukan pimpinan perusahaan dalam memutuskan promosi yang akan diberikan kepada semua karyawan. Perlakuan sama bagi seluruh karyawan merupakan gambaran awal tentang adanya kesetaraan atau keadilan dan perlakuan sama yang diberlakukan dan diterima laki-laki dan perempuan yang menjadi karyawan di Riau Televisi.

Temuan di lapangan menunjukkan tidak terdapat perbedaan sistem penilaian antar kedua jenis kelamin. Penilaian yang dilakukan bertingkat ini, pada akhirnya bermuara kepada keputusan direktur utama yang memiliki kewenangan penuh dalam memutuskan promosi terhadap seorang karyawan. Selain penilaian yang menjadi pertimbangan bagi keputusan yang diambil, faktor pengalaman dan kemampuan yang keduanya dihasilkan dari masa kerja yang panjang, menjadi pertimbangan lainnya dalam keputusan promosi seorang karyawan untuk ditempatkan di posisi yang lebih tinggi. Keempat perempuan yang menjadi informan penelitian ini merupakan karyawan yang memenuhi persyaratan dan kriteria yang dibutuhkan untuk menempati posisi manajer.

\section{Simpulan}

Dari hasil analisis data yang dilakukan peneliti, melalui pengamatan langsung dan wawancara dengan 
jurnalis perempuan yang menduduki jabatan sebagai manajer di Riau TV. Jadi kesimpulannya adalah bahwa tindakan Direktur Televisi Riau menempatkan posisi perempuan sebagai manajer di beberapa divisi TV Riau karena faktor sosial, maka Manajer Perempuan di Riau Televisi hanya sebagai strata sosial. Promosi Jabatan yang tidak Diskriminatif Gender di Riau TV terlihat dari cara Direktur Utama yang memiliki wewenang untuk menunjuk seorang karyawan ke posisi manajer tertentu dalam struktur perusahaan. Penempatan karir bagi manajer perempuan menunjukkan dimensi kesetaraan gender buikan diperalat. Hal ini dapat dilihat cara Direktur Utama dalam memperlaukan karyawan tidak menganut budaya patriarki, sehingga keempat wanita yang memiliki pengalaman kerja dan kemampuan kerja yang baik (propesisme) dapat menduduki posisi manajerial tertentu setelah dipromosikan dan dianggap pantas di depan umum. 


\section{DAFTAR PUSTAKA}

Afrizal. (2014). Metode Penelitian Kualitatif: Sebuah Upaya Mendukung Penggunaan Penelitian Kualitatif dalam Berbagai Disiplin Ilmu. Jakarta: Rajawali Pers.

Angeliqa, Fitria dan Iswahyuningtyas, Cici Eka. (2014). "Kesetaraan Gender dan Peningkatan Partisipasi Perempuan dalam Produksi Program Televisi", Seminar Besar Nasional Komunikasi, Komunikasi @2014, 465-472.

Agustino, Leo. (2013). Langkah Besar Perempuan Indonesia (atau Sebaliknya?): Telaah Kritis Perempuan dalam Media, dalam: Sastriyani, Siti Hariti (ed.). (2013). Women in Public Sector [Perempuan di Sektor Publik]. Yogyakarta: Tiara Wacana.

Aripurnami, Sita. (2013). “Transformasi Garakan dan Menguatnya Kepemimpinan Perempuan." Afirmasi Jurnal Pemikiran Feminis. Vol. 02.

Bogdan, Robert dan Steven J. Taylor. (2013). Kualitatif (Dasar-DasarPenelitian). Surabaya: Usaha Nasional.

Burke, Ronald, et al. (2005), Advancing women's careers. Career Development International . Vol. 10, No. 3, pp. 165-167.

Budiman, Arief. (2015). Pembagian Kerja Secara Seksual. Jakarta: Gramedia.

Bungin, Burhan. (2012). Metodologi Penelitian Kualitatif: Aktualisasi Metodologis ke Arah Ragam Varian Kontemporer. Jakarta: Rajawali Press.

Cai, Yuan and Kleiner, Brian H. (1999), Sex discrimination in hiring:the glass ceiling. Vol. 18, No. 2/3/4. 
Dwi N, Susilastuti. (2008). “Penggambaran Kiprah Perempuan di Sektor Publik di Media Masih Suram", dalam Sastriyani, Siti Hariti (ed.). 2008. Women in Public Sector [Perempuan di Sektor Publik]. Yogyakarta: Tiara Wacana.

Giddens, Anthony. (2010). Teori Strukturasi Dasar-Dasar Pembentukan Struktur Sosial Masyarakat. Yogyakarta: Pustaka Pelajar.

Henslin, James M. (2007). Sosiologi dengan Pendekatan Membumi, Edisi 6 Jilid 2. Jakarta: Penerbit Erlangga.

Holzner, Brigitte. (1997). "Penelitian Berorientasi Gender", dalam: Saptari, Ratna. (1997). Perempuan Kerja dan Perubahan Sosial, Sebuah Pengantar Studi Perempuan. Jakarta: Pustaka Utama Grafiti.

Jones, Pip. (2010). Pengantar Teori-Teori Sosial, Dari Teori Fungsionalisme Hingga Post-Modernisme. Jakarta: Yayasan Pustaka Obor.

Kinanti, Pratiwi Asih. (2013). "Kesetaraan Gender dalam Iklan Media Cetak Prancis", FIB UI, t.v (t.e), 1-9

Kusno, Gustaaf. (2015). “Glass Ceiling" Diskriminasi Bagi Wanita." Kompasiana.com. (http://www. google.co.id/amp/www.kompasiana.com/amp/ gustaafkusno/glass-ceiling-diskriminasi-bagiwanita. diakses 10 Mei 2017).

Lidyah, Rika. (2017). “Posisi Manajer Untuk Wanita: Kendala dan Pandangan Islam", An Nisa'a: Jurnal Kajian Gender dan Anak. Volume 12, Nomor 01, Juni 2017

Moleong, Lexi J. (2011). Metode Penelitian Kualitatif. Bandung: Remaja Rosdakarya. 
Muslim, Muhamad Ihwanul dan Perdhana, Mirwan Surya. (2017). "Glass Ceiling: Sebuah Studi Literatur", Jurnal Bisnis Strategi, Vol. 26 No. 1, 28-38.

Narwoko, J. Dwi dan Bagong Suyanto (ed.). (2013). Sosiologi Teks Pengantar dan Terapan. Edisi Keempat. Jakarta: Kencana Prenada Media.

Nugroho, Riant. (2014). Gender dan Strategi Pengarusutamaannya di Indonesia. Yogyakarta: Pustaka Pelajar.

Nursalim. (2011). “Diskriminasi Gender Di Media Televisi', Marwah, t.v (t.e), 1-9

Purnamasari, Dewi Laily. Beijing Platform for Action (1995). Kompasiana.com. (http://www.kompasiana. com/dewilailypurnamasari/beijing-platform-foraction-1995 diakses 11 Februari 2018.

Stoner, James A. F. et. al. (n.y). Manajemen; Jilid 1; Edisi bahasa Indonesia. Jakarta: PT Prenhallindo

Sarwono, Billy K. ((2013). Saatnya Media Pro Perempuan: Perspektif Gender dalam Kajian Media. Jakarta: Departemen Ilmu Komunikasi, Fakultas Ilmu Sosial dan Ilmu Politik, Universitas Indonesia.

Satriani. (2017). “Eksistensi Jurnalis Perempuan dalam Kesetaraan Gender di Harian Amanah Kota Makassar", Penelitian, Jurusan Jurnalistik Fakultas Dakwah dan Komunikasi Universitas Islam Negeri (Uin) Alauddin Makassar.

Stewart, Susan. (2012). Belajar Bersama, Buku Sumber Partisipastif Pelatih Pertanian, diterjemahkan oleh Niko Adris. Arkansas: Heifer Project International dan Christian Veterinary Missions.

Sugiyono. (2012). Metode Penelitian Kuantitaif, Kualitatif, dan 
RED. Bandung: Alfabeta.

Wirawan, Ida Bagus. (2015). Teori-Teori Sosial Dalam Tiga

Paradigma (Fakta Sosial, Definisi Sosial, dan Perilaku Sosial). Jakarta: Kencana Prenada.

Wijayanti. (2009). “Glass Ceiling dalam Karir Wanita Mampukah Wanita Mengatasi Glass Ceiling?", Segmen, No. 2 Juli.

Wentling, Rose Mary (2003). “The Career development and aspiration of women in middle management revisited". Women in management Review. Vol. 18, No. 6, pp 311-324.

Weyer, Birgit (2007). "Twenty years later: explaining the persistence of glass ceiling for women leaders". Women in management Review. Vol. 22, No.6, pp 482496. 
Nurhadi dan Donny Haris 